\title{
Effects of Eicosapentaenoic Acid on Arterial Calcification
}

\author{
Yukihiro Saito, Kazufumi Nakamura * and Hiroshi Ito \\ Department of Cardiovascular Medicine, Okayama University Graduate School of Medicine, \\ Dentistry and Pharmaceutical Sciences, Okayama 700-8558, Japan; gsaito8976@gmail.com (Y.S.); \\ itomd@md.okayama-u.ac.jp (H.I.) \\ * Correspondence: ichibun@cc.okayama-u.ac.jp; Tel.: +81-86-235-7351; Fax: +81-86-235-7353
}

Received: 29 June 2020; Accepted: 27 July 2020; Published: 30 July 2020

\begin{abstract}
Arterial calcification is a hallmark of advanced atherosclerosis and predicts cardiovascular events. However, there is no clinically accepted therapy that prevents progression of arterial calcification. HMG-CoA reductase inhibitors, statins, lower low-density lipoprotein-cholesterol and reduce cardiovascular events, but coronary artery calcification is actually promoted by statins. The addition of eicosapentaenoic acid (EPA) to statins further reduced cardiovascular events in clinical trials, JELIS and REDUCE-IT. Additionally, we found that EPA significantly suppressed arterial calcification in vitro and in vivo via suppression of inflammatory responses, oxidative stress and Wnt signaling. However, so far there is a lack of evidence showing the effect of EPA on arterial calcification in a clinical situation. We reviewed the molecular mechanisms of the inhibitory effect of EPA on arterial calcification and the results of some clinical trials.
\end{abstract}

Keywords: eicosapentaenoic acid; atherosclerosis; Klotho

\section{Introduction}

Arterial calcification is often observed in patients with atherosclerosis, chronic kidney disease (CKD) and diabetes mellitus. Coronary artery calcification detected by computed tomography (CT) reflects atherosclerotic plaque burden and predicts cardiovascular events [1,2]. Additionally, aortic calcification predicts mortality and nonfatal cardiovascular events in dialysis patients [3]. However, macrocalcifications occurring in the intimal plaque during late-stage calcification are believed to stabilize the plaque [4]. On the other hand, microcalcifications occurring during the early-stage calcification correlate with plaque vulnerability that results in myocardial and cerebral infarction, but it is difficult to detect microcalcifications using a clinical CT scan [5]. Medial calcification causes arterial stiffness that is a predictor of coronary heart disease and stroke [6,7].

Lowering low-density lipoprotein-cholesterol (LDL-C), which is an established therapy for cardiovascular diseases, promotes formation of coronary artery macrocalcifications [8-10]. Although there is no clinically established therapy for arterial calcification, some molecules are expected to reduce arterial calcification, for example, eicosapentaenoic acid (EPA), vitamin K1, magnesium, spironolactone and evolocumab [11-16].

Purified EPA has been prescribed to lower triglycerides in Japan. EPA inhibits osteoblastic change and mineralization in vascular cells [17]. Similarly to Kanai et al., we found that EPA significantly suppressed arterial calcification in experimental studies using small animals $[18,19]$. Thus, we expect that lowering arterial calcification by EPA leads to a reduction of cardiovascular events. Although docosahexaenoic acid (DHA) also inhibits calcification of vascular cells in vitro, it raises serum LDL-C levels, which could be a risk of cardiovascular diseases [17,20,21]. 
In the Reduction of Cardiovascular Events with Icosapent Ethyl-Intervention Trial (REDUCE-IT) and the Japan EPA Lipid Intervention Study (JELIS) using highly purified EPA, EPA significantly reduced the risk of cardiovascular events [22-24]. However, the effect of EPA on arterial calcification in a clinical situation is not established. While the blood level of omega-3 fatty acid was shown to be inversely associated with coronary artery calcification in some observational studies, pitavastatin plus EPA did not reduce the progression of coronary artery calcification compared with the effect of pitavastatin alone in patients with hypercholesterolemia [25-28]. Since there is a discrepancy in the effect of EPA among the results of clinical observational, clinical interventional and experimental studies, we reviewed the effect of EPA on arterial calcification.

\section{EPA}

EPA is a polyunsaturated long-chain fatty acid found in fish oil with a 20-carbon backbone and five cis-double bonds at positions 5, 8, 11, 14 and 17. During an inflammatory response, arachidonic acid and EPA are metabolized by cyclooxygenases and lipoxygenases to form eicosanoids. Eicosanoids derived from EPA, prostaglandin-3 family, thromboxane-3 family and leukotriene- 5 family are less potent inducers of inflammation, blood vessel constriction, and thrombus formation than eicosanoids derived from arachidonic acid, prostaglandin-2 family, thromboxane-2 family and leukotriene- 4 family. Additionally, E-series resolvins are attractive metabolites derived from EPA that work as specialized pro-resolving mediators $[29,30]$.

\section{Effect of Highly Purified EPA on Cardiovascular Disease}

Statin therapy for lowering LDL-C decreases the risk of coronary heart disease and mortality [31]. However, residual risk persists even after the achievement of target LDL-C levels. Low levels of high-density lipoprotein-cholesterol and high level of triglycerides are residual risks that cannot be controlled by LDL-C lowering therapy with statins. However, previous trials with fibrates or niacin for lowering triglycerides failed to reduce events after LDL-C levels were controlled with statins [32-34]. Additionally, n-3 fatty acid products were not beneficial for patients receiving statin therapy in some previous trials [35-37]. On the other hand, treatment with $1.8 \mathrm{~g}$ /day purified EPA plus statin therapy resulted in a 19\% relative risk reduction in major coronary events in the JELIS (statin plus EPA, $2.8 \%$ vs. statin alone, 3.5\%) [23]. However, that study was a non-blinded randomized controlled trial (RCT).

The REDUCE-IT, a blinded RCT, also demonstrated that $4 \mathrm{~g}$ /day purified EPA reduced cardiovascular events: a composite of cardiovascular death, nonfatal myocardial infarction, nonfatal stroke, coronary revascularization and unstable angina for EPA vs. placebo was $17.2 \%$ vs. $22.0 \%$ [22,24]. However, the cardiovascular risk reduction was not associated with attainment of more normal triglyceride levels in REDUCE-IT [22]. These results suggest that lowering triglycerides does not mainly contribute to the risk reduction and that there is another specific target of highly purified EPA. Actually, various beneficial effects of EPA on atherosclerosis have been reported [38]. The serum level of small dense LDL, especially common in the serum of patients with atherosclerosis and susceptible to chemical modifications increasing its atherogenicity, was reduced by $1.8 \mathrm{~g} /$ day EPA, indicating that EPA improves lipoprotein profiles [39,40]. Additionally, EPA was preferentially incorporated into the thin-cap plaque rather than the thick-cap plaque and reduced atherosclerotic lesions in some mouse models. Atheroma formation in ApoE-deficient mice and LDL receptor-deficient mice and aortic aneurysm formation in osteoprotegerin-deficient/ApoE-deficient mice were prevented by orally administered EPA through anti-inflammatory effects [41-44]. 


\section{Arterial Calcification in Cardiovascular Disease}

\subsection{Arterial Calcification and Clinical Prognosis}

Arterial calcification is a hallmark of advanced atherosclerosis. Standard coronary risk factors are related to both the incidence and progression of coronary artery calcification [45]. An annual calcium score progression of $>15 \%$ is associated with worse mortality [46].

Pathomorphologically, arterial calcification can be divided into two distinct entities according to the calcified sites within the arterial wall: patchy calcification of the intima close to lipid deposits as present in plaque calcification and calcification of the media without lipid deposits, known as Mönckeberg-type [47]. Both types are often observed in patients with cardiovascular disease induced by diabetes mellitus, metabolic syndrome, CKD, and aging [48].

Arterial calcification evaluated by CT is a predictor of cardiovascular events [2,49-51]. There are several biological mechanisms by which arterial calcification increases cardiovascular mortality. Coronary arterial intimal calcification, particularly microcalcification within the fibrous cap, is thought to increase the risk of plaque rupture and thrombus formation resulting in myocardial infarction $[52,53]$. However, it is difficult to see microcalcification by a clinical CT scan due to its low spatial resolution. On the other hand, macrocalcification can be identified using CT and is widely believed to stabilize the plaque $[54,55]$. Arterial medial calcification increases arterial stiffness, which causes systolic hypertension, diastolic dysfunction, decreased coronary perfusion and heart failure [50,56,57].

\subsection{Arterial Calcification and Drug Therapy for Cardiovascular Disease}

Several recent studies with large sample sizes have suggested that statins promote vascular calcification, even though LDL-C-lowering treatment with statins is an established drug therapy for patients with coronary artery disease $[8,9,58]$. That is, statins regress atheroma volume but promote macrocalcifications. From these findings, progression of macrocalcifications by statins may be one of the mechanisms by which vulnerable plaque is stabilized [59]. Atorvastatin increased atherosclerotic plaque calcification also in $\mathrm{ApoE}^{-/-}$mice [60]. Statins activate Rac1 in macrophages, resulting in Rac1-dependent interleukin $1 \beta$ upregulation and consequent calcification [60-62].

Fibrates and niacin, other lipid-lowering drugs, do not suppress the progression of arterial calcification caused by statins. Interestingly, evolocumab, a proprotein convertase subtilisin-kexin type 9 (PCSK9) inhibitor, could suppress the increase in coronary artery calcification caused by statins [14]. Plasma PCSK9 concentration has been shown to be associated with coronary artery calcification in untreated patients with angina-like chest pain [63]. Statins decrease intracellular cholesterol in the liver and increase PCSK9 as well as LDL receptors [64]. Therefore, a PCSK9 inhibitor might cancel the action of PCSK9 increased by statin treatment and prevent arterial calcification. However, another study did not detect the inhibitory effect of evolocumab on calcification [65].

\section{Molecular Mechanisms of Arterial Calcification}

Although arterial calcification initially seemed to be a passive process resulting from oversaturation of plasma with calcium and phosphate, it has become clear that it is a highly regulated process involving several cell types and molecular mechanisms $[66,67]$. While inflammation and oxidative stress generally cause intimal calcification [68], uremia and high serum levels of calcium and phosphate drive medial calcification [69]. Additionally, complex mechanisms are common in both intimal calcification and medial calcification. The mechanism included failed anti-calcification processes due to loss of calcification inhibitors including osteoprotegerin, osteopontin, matrix Gla protein (MGP), fetuin-A and pyrophosphate [48,70-73], induction of osteo/chondroblast-like cells producing extracellular vesicles [74], cell death resulting in release of apoptotic bodies or necrotic debris that cause nucleation of apatite [75], calcium/phosphate dysregulation causing deposits calcium phosphate hydroxyapatite [76], nucleation complexes formed during bone remodeling, and matrix degradation/modification [77]. 


\section{Inhibitory Effects of EPA on Arterial Calcification in Experimental Studies}

Several experimental studies have demonstrated that EPA suppresses arterial calcification in vitro and in vivo via various mechanisms (Table 1). MCP-1, monocyte chemotactic protein-1; MMP, matrix metalloproteinase; NOX, NADPH oxidase; GPR120, G-protein coupled receptor 120; PPAR $\gamma$, peroxisome proliferator-activating receptor gamma; NF- $\mathrm{kB}$, nuclear factor- $\mathrm{kB}$; ACSL3, Acyl-CoA synthetase long chain family member 3 .

Table 1. Effects of Eicosapentaenoic Acid (EPA) on Arterial Calcification in Experimental Studies.

\begin{tabular}{|c|c|c|c|c|c|}
\hline $\begin{array}{l}\text { Induction of Arterial } \\
\text { Calcification }\end{array}$ & Species & $\begin{array}{l}\text { In Vivo or } \\
\text { In Vitro }\end{array}$ & $\begin{array}{l}\text { Suppression } \\
\text { of Calcification }\end{array}$ & Mechanisms & Reference \\
\hline Warfarin & Rat & in vivo & $\begin{array}{c}\text { Aorta } \\
\text { calcification }\end{array}$ & $\begin{array}{l}\text { Suppression of macrophage } \\
\text { infiltration, MCP-1 } \\
\text { expression and MMP } \\
\text { activity in the aorta. }\end{array}$ & [19] \\
\hline Klotho deficiency & Mouse & in vivo & $\begin{array}{c}\text { Aorta } \\
\text { calcification }\end{array}$ & $\begin{array}{l}\text { Suppression of NOX activity } \\
\text { inducing oxidative stress via } \\
\text { activation of GPR120 } \\
\text { signaling in aortic smooth } \\
\text { muscle cells. }\end{array}$ & [18] \\
\hline $\begin{array}{l}\text { Activation of Wnt } \\
\text { signaling }\end{array}$ & Human & in vitro & $\begin{array}{l}\text { Osteogenic } \\
\text { change }\end{array}$ & $\begin{array}{l}\text { Suppression of Wnt } \\
\text { signaling via PPAR } \gamma \text { in } \\
\text { smooth muscle cells. }\end{array}$ & [78] \\
\hline Palmitic acid & Human & in vitro & $\begin{array}{c}\text { Osteogenic } \\
\text { change } \\
\text { Mineralization }\end{array}$ & $\begin{array}{l}\text { Suppression of NF-кB } \\
\text { signaling via ACSL3 } \\
\text { downregulation in aortic } \\
\text { smooth muscle cells. }\end{array}$ & [79] \\
\hline
\end{tabular}

\subsection{Warfarin-Induced Arterial Calcification}

Warfarin antagonizes vitamin K and blocks gamma-carboxylation of MGP and induces vascular calcification. MGP has been identified as a vitamin K-dependent protein and a calcification inhibitor in cartilage and the vasculature. MGP-deficient mice develop widespread aortic and arterial calcification $[80,81]$. MGP is an independent predictor of both intimal and medial vascular calcification in CKD [82]. It binds to bone morphogenetic protein (BMP)-2, triggering the transformation of vascular smooth muscle cells to osteoblast-like cells, and inhibits the osteoinductive effect of BMP-2 [83,84]. The function of MGP depends on its gamma-carboxyglutamic acid residues. To modify the residues, vitamin $\mathrm{K}$ is required as a co-factor [85-88].

Kanai et al. demonstrated that EPA prevents warfarin-induced arterial medial calcification in rats [19]. EPA suppresses osteogenetic marker expression, macrophage infiltration, matrix metalloproteinase (MMP) activity and monocyte chemotactic protein-1 (MCP-1) expression in the aorta.

\subsection{Hypomorphic Klotho-Induced Arterial Calcification}

Klotho ( $\alpha$-Klotho) was identified as an anti-aging hormone in mice [89]. Klotho is a coreceptor of fibroblast growth factor 23 and regulates calcium/phosphate metabolism and vitamin D synthesis. Klotho overexpression extends the life span in mice [90]. Hypomorphic mutant Klotho [kl/kl] mice exhibit accelerated aging phenotypes including arteriosclerosis, ectopic calcification, osteoporosis, pulmonary emphysema, muscle atrophy and short life span [91]. Extensive medial calcification is observed in the aorta and middle-sized muscular arteries. The vascular changes seen in $\mathrm{kl} / \mathrm{kl}$ mice are similar to Mönckeberg-type arteriosclerosis in humans. Also in humans, low serum KLOTHO levels are associated with the prevalence of cardiovascular disease and all-cause mortality [91,92]. Furthermore, KL mRNA and KLOTHO protein levels decrease in the kidneys of patients with chronic kidney disease and there is an inverse association between serum KLOTHO level and arterial stiffness in patients with chronic kidney disease $[93,94]$. 
We found that orally administered EPA significantly suppresses aortic calcification induced in $\mathrm{kl} / \mathrm{kl}$ mice $[18,89]$. The reduction of aortic calcification in living mice was detected by a multi-detector CT scan in a clinical situation. The levels of NADPH oxidase-4 (NOX4) mRNA expression and NOX activity in aortic smooth muscle cells isolated from $\mathrm{kl} / \mathrm{kl}$ mice are higher than those in cells isolated from wild type mice. EPA-supplemented media suppresses NOX4 mRNA upregulation and NOX activity observed in smooth muscle cells from $\mathrm{kl} / \mathrm{kl}$ mice. Elevated oxidative stress promotes arterial calcification, and NOX is a major source of reactive oxygen species in atherosclerosis $[95,96]$. EPA reduces NOX activity via free fatty acid receptor 4 (FFAR4), also known as G-protein-coupled receptor 120 (GPR120). Additionally, Klotho downregulates PIT1, a sodium-dependent phosphate transporter, to suppress phosphate uptake, in addition to enhancing phosphaturia. Therefore, a decrease of Klotho leads to mineralization in response to phosphate uptake [16,97]. Even though EPA does not improve hyperphosphatemia, progression of calcification is prevented by EPA in $\mathrm{kl} / \mathrm{kl}$ mice [18]. This suggests that EPA might suppress phosphate uptake in smooth muscle cells.

\subsection{Wnt Signaling-Induced Osteogenic Changes in Vascular Smooth Muscle Cells}

The Wnt signaling pathway is an evolutionarily conserved pathway regulating cell proliferation and differentiation in development, stem cell renewal, and cancer progression [98,99]. This signaling pathway is also involved in various aging phenotypes including chronic lung diseases, renal fibrosis and arterial calcification [100-103].

CMV-Msx2 transgenic (CMV-Msx2 $\mathrm{Tg}^{+}$) mice fed a high-fat diet exhibit marked cardiovascular calcification involving the aorta and coronary artery [104]. Msx2 suppresses the expression of Dkk1, a Wnt inhibitor, in the aorta. TOPGAL ${ }^{+}$; CMV-Msx2 $\mathrm{Tg}^{+}$mice exhibit augmented aortic LacZ expression, suggesting enhanced Wnt signaling.

Wnt signaling is over-activated also in $\mathrm{kl} / \mathrm{kl}$ mice, because Klotho inhibits the binding of Wnt ligands to their receptors [105]. Omega-3 fatty acids suppress Wnt signaling in cancer cells [106,107]. This suggests that EPA may antagonize Wnt signaling also in $\mathrm{kl} / \mathrm{kl}$ mice and prevent progression of arterial calcification.

In human aortic smooth muscle cells, activation of Wnt signaling induces the expression of osteogenic genes $[78,108]$. EPA suppresses not only the expression of these osteogenic genes but also the expression of Wnt signaling marker genes via upregulation of peroxisome proliferator-activating receptor gamma (PPAR $\gamma$ ) [78]. PPAR $\gamma$ activates secreted frizzled-related protein 2 (SFRP2) and counteracts vascular calcification induced by Wnt5a in mice [109]. Additionally, EPA upregulates Klotho in the kidney [78].

On the other hand, decreased Wnt signaling has emerged as a risk factor for cholesterol accumulation, foam cell formation and atherosclerosis [110]. Therefore, the mechanism is not simple.

\subsection{Palmitic Acid-Induced Osteogenic Changes in Vascular Smooth Muscle Cells}

Stearoyl-CoA desaturase (SCD) enzymes catalyze the conversion of saturated fatty acids to monounsaturated fatty acid, that is, they regulate the intracellular balance of saturated and unsaturated fatty acids [111-113]. Mice with smooth muscle cell-specific deletion of Scd1 and Scd2 show severe vascular calcification with increased endoplasmic reticulum stress [114]. Higher dietary intakes of major saturated fatty acids are associated with an increased risk of coronary heart disease $[115,116]$. Palmitic acid, a saturated long chain fatty acid with a 16-carbon backbone, induces apoptosis, oxidative stress and endoplasmic reticulum stress and increases medial calcification [117].

In human aortic smooth muscle cells, EPA suppresses osteoblastic differentiation and mineralization induced by palmitic acid through Acyl-CoA synthetase long chain family member 3 (ACSL3) and nuclear factor- $\mathrm{KB}(\mathrm{NF}-\mathrm{\kappa B})$ [79]. ACSL3 is highly expressed in vascular smooth muscle cells and macrophages in human non-calcifying and calcifying atherosclerotic plaques from carotid arteries. ACSL3 is an enzyme that converts palmitic acids to palmitoyl-CoA, and the metabolite activates the NF- $\mathrm{kB}$ signaling 
pathway. Palmitic acid upregulates ACSL3 expression prior to osteoblastic gene induction, and EPA suppresses the upregulation of ACSL3 induced by palmitic acid.

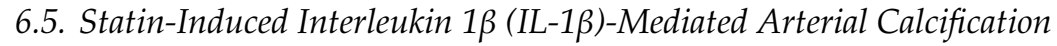

IL-1 $\beta$ is an inflammatory cytokine produced by activated macrophages. Statins reduce cardiovascular events, but they promote IL-1 $\beta$ production and consequent plaque calcification and insulin resistance $[60,118]$. Canakinumab, a therapeutic monoclonal antibody targeting interleukin-1 $\beta$, inhibits aortic calcification in LDLR $^{-/-}$mice [119]. In the CANTOS trial, canakinumab significantly reduced high-sensitivity C-reactive protein levels and cardiovascular event rates, and $93.4 \%$ of the patients were treated with statins [120]. These results suggest that the addition of drugs suppressing IL-1 $\beta$ to statins may be effective for suppression of statin-induced calcification. EPA suppresses IL-1 $\beta$ expression in rheumatoid arthritis model rats and Thy-1 nephritis model rats [121,122].

\section{Effects of EPA on Arterial Calcification in Clinical Studies}

Blood levels of n-3 polyunsaturated fatty acid and omega-3 index and the percentages of EPA and docosahexaenoic acid (DHA) in total fatty acids present in the erythrocyte membrane have been shown to be inversely associated with coronary artery calcification in some observational studies $[25,27,28]$. On the other hand, we reported that $1.8 \mathrm{~g} /$ day EPA does not attenuate progression of coronary artery calcification evaluated by $\mathrm{CT}$ in pitavastatin-treated patients with hypercholesterolemia who were asymptomatic for cardiovascular disease during a period of 12 months [26]. Evaluation using optical coherence tomography and intravascular ultrasound showed that the addition of $1.8 \mathrm{~g} /$ day EPA to statin therapy does not change the calcified plaque volume, even though it does stabilize and reduce plaques of human coronary arteries [123-125]. In an ongoing trial, the EVAPORATE study, changes in coronary plaque, including low-attenuation, fibro-fatty, fibrous, calcified and non-calcified plaque, over a period of 9 to 18 months are being examined in patients treated with statins plus a higher dose of EPA, $4 \mathrm{~g} /$ day [11]. The results of interim analysis at nine months, which were presented in 2019 AHA Scientific Sessions (Philadelphia, PA), indicated slowed progression of calcified plaque: EPA, $1 \%$ decrease vs. placebo, $9 \%$ increase, $p=0.001$ [126]. These clinical studies were summarized in Table 2. CT, computed tomography; OCT, optical coherence tomography; $\mathrm{PCI}$, percutaneous coronary intervention; IVUS, intravascular ultrasound. 
Table 2. Effects of EPA on Arterial Calcification in Clinical Studies.

\begin{tabular}{|c|c|c|c|c|c|c|c|c|}
\hline Author & Year & Region & Study Patients & Group & EPA Dose & $\begin{array}{l}\text { Evaluation } \\
\text { Method }\end{array}$ & Duration & Effect on Calcification \\
\hline $\begin{array}{l}\text { Miyoshi et al. } \\
\text { [26] }\end{array}$ & 2018 & Japan & $\begin{array}{l}\text { Patients with Agatston score 1-999, } \\
\text { LDL-C levels } \geq 140 \mathrm{mg} / \mathrm{dL} \text {, and no } \\
\text { history of atherosclerotic } \\
\text { cardiovascular disease }\end{array}$ & $\begin{array}{l}\text { Pitavastatin vs. } \\
\text { Pitavastatin plus EPA }\end{array}$ & $1.8 \mathrm{~g} /$ day & $\mathrm{CT}$ & 12 months & $\begin{array}{l}\text { No significant difference } \\
\text { in annual percent changes } \\
\text { in Agatston score and } \\
\text { calcium volume score. }\end{array}$ \\
\hline Niki et al. [124] & 2016 & Japan & $\begin{array}{l}\text { Statin-treated patients with stable } \\
\text { angina scheduled to be treated } \\
\text { with PCI }\end{array}$ & Statin vs. Stain plus EPA & $1.8 \mathrm{~g} / \mathrm{day}$ & IVUS & 6 months & $\begin{array}{l}\text { No significant difference } \\
\text { in percent change in } \\
\text { calcium volume. }\end{array}$ \\
\hline $\begin{array}{l}\text { Watanabe et al. } \\
\text { [125] }\end{array}$ & 2017 & Japan & $\begin{array}{l}\text { Patients with hypercholesterolemia, } \\
\text { stable angina or acute coronary } \\
\text { syndrome who have received } \\
\text { successful PCI with IVUS guidance }\end{array}$ & $\begin{array}{l}\text { Pitavastatin vs. } \\
\text { Pitavastatin plus EPA }\end{array}$ & $1.8 \mathrm{~g} /$ day & IVUS & $6-8$ months & $\begin{array}{l}\text { No significant difference } \\
\text { in calcium volume in } \\
\text { non-stenting lesions. }\end{array}$ \\
\hline Budoff et al. [11] & ongoing & USA & $\begin{array}{l}\text { Statin-treated patients with coronary } \\
\text { atherosclerosis, fasting triglyceride } \\
\text { levels of } 135 \text { to } 499 \mathrm{mg} / \mathrm{dL} \text {, and } \\
\text { LDL-C levels of } 40 \text { to } 115 \mathrm{mg} / \mathrm{dL} \text {. }\end{array}$ & Statin vs. Stain plus EPA & $4 \mathrm{~g} /$ day & $\mathrm{CT}$ & 18 months & ongoing \\
\hline
\end{tabular}




\section{Future Challenges and Possible Solutions}

Unfortunately, there is no clinically established therapy to suppress arterial calcification. We need to think about why EPA does not suppress arterial calcification in a clinical situation even though EPA significantly suppresses arterial calcification in experimental models. The dose might be too low to suppress calcification in patients, because the doses used in experimental animals were very high (the food intake of mice is generally $3-5 \mathrm{~g} /$ day and the body weight is generally $20 \mathrm{~g} ; 5 \%(w / w)$ EPA roughly corresponds to $7.5-12.5 \mathrm{~g}$ EPA $/ \mathrm{kg}$ in mice.) $[18,19]$. In the JELIS, mean plasma EPA concentrations and the EPA/AA ratio were $170 \mu \mathrm{g} / \mathrm{mL}$ and 1.21, respectively, in patients treated with $1.8 \mathrm{~g} /$ day EPA [23]. In the REDUCE-IT, the mean plasma EPA concentration was $144.0 \mu \mathrm{g} / \mathrm{mL}$ in patients treated with $4 \mathrm{~g} /$ day EPA [22]. The mean plasma EPA concentrations and EPA/AA ratio were $393.5 \mu \mathrm{g} / \mathrm{mL}$ and 9.15, respectively, in 5\% (w/w) EPA-fed kl/kl mice [18]. Thus, the serum level of EPA and the EPA/AA ratio were also very high in the experimental study.

Since it is difficult to use such a high dose in a clinical situation, we need to identify a specific target and develop small molecules or oligonucleotide therapeutics that are effective for arterial calcification.

\subsection{Activation of GPR120 Signaling}

GPR120 is a member of the rhodopsin family of G-protein-coupled receptors for long chain fatty acids [127]. GPR120 mediates anti-inflammatory and insulin-sensitizing effects of omega-3 fatty acids [128]. Since EPA suppresses arterial calcification and aortic aneurysm through GPR120, specific activation of GPR120 signaling might be more effective [18,43].

\subsection{Activation of ChemR23 Signaling}

Serum resolvin E1 levels are higher in EPA-fed mice [18]. Resolvin E1, a metabolite derived from EPA, exhibits resolving inflammation effects at a low dose and also inhibits phosphate-induced calcification of vascular smooth muscle cells through chemokine like receptor 1 (CMKLR1), also known as ChemR23 [129,130]. Interestingly, chemerin, one of the adipokines, also inhibits phosphate-induced calcification in vascular smooth muscle cells through ChemR23 [131]. Thus, activation of ChemR23 signaling also might be a good target of arterial calcification.

\subsection{Identification of Other Specific Targets of EPA}

Since the inhibitory effect of EPA on arterial calcification has been established in experimental animal models, omics analysis might be useful for identifying specific target molecules or signaling pathways of EPA.

However, the clinical significance of the progression of coronary calcification remains controversial. Progression of coronary calcification is an independent factor of mortality [46]. On the other hand, aggressive lipid lowering with high-dose statins promotes coronary calcification [59].

\section{Summary}

In this review, we summarized the effects of EPA on arterial calcification. The proposed mechanisms are summarized in Figure 1. Purified EPA, which has anti-atherogenic effects in patients with cardiovascular disease, prevented arterial calcification in experimental studies. However, the efficacy of EPA for prevention of arterial calcification in patients has not been established and further studies are needed. 


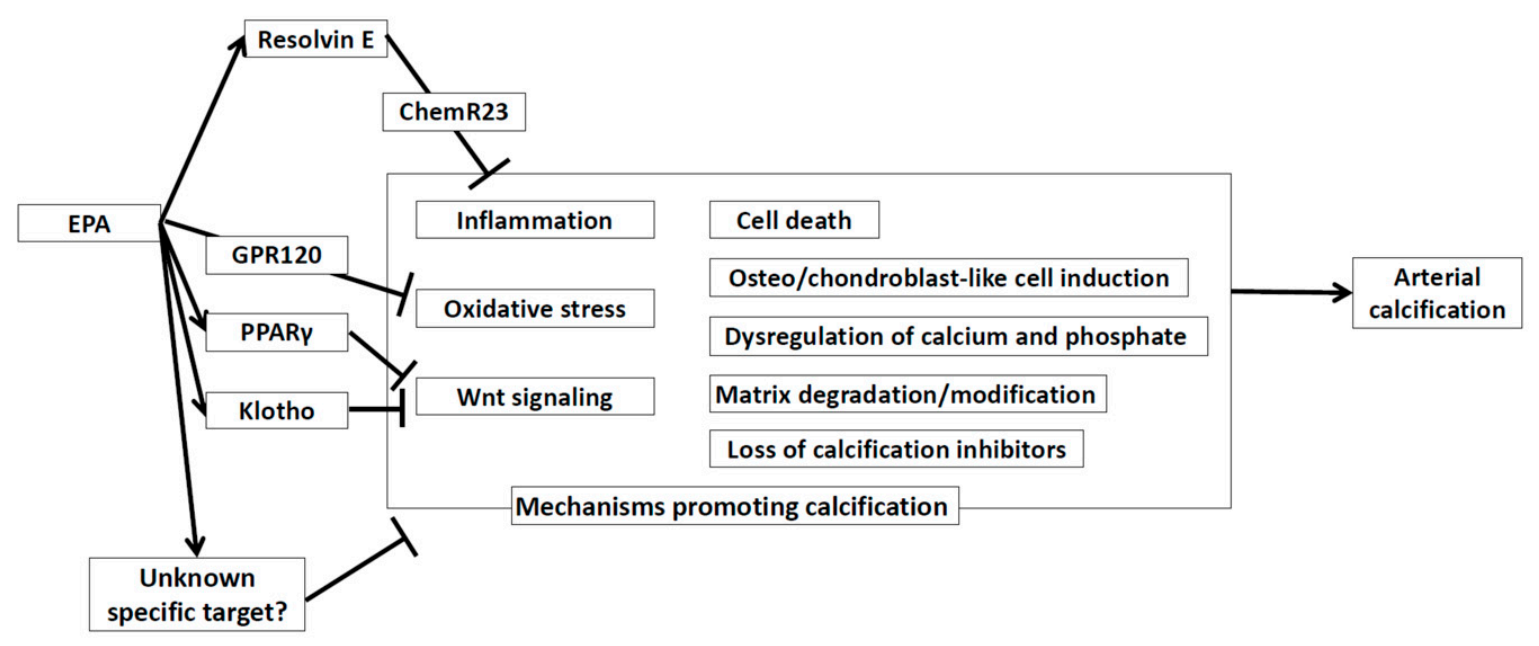

Figure 1. Proposed mechanisms on how EPA affects arterial calcification. EPA: Eicosapentaenoic Acid. ChemR23: Chemerin receptor 23. EPA: eicosapentaenoic acid. GPR120: G-protein coupled receptor 120. PPAR $\gamma$ : Peroxisome Proliferator-Activated Receptor $\gamma$.

Author Contributions: Y.S. and K.N. prepared the manuscript. H.I. provided supervision. All authors have read and agree to the published version of the manuscript.

Funding: This work was supported in part by Grants-in-Aid for Scientific Research from the Ministry of Education, Culture, Sports, Science and Technology, Tokyo, Japan (Ito H; 19K08558 and Nakamura K; 18K08037).

Acknowledgments: We thank Kaoru Akazawa, Megumi Kondo, and Masayo Ohmori for their excellent technical assistance.

Conflicts of Interest: Nakamura received lecture fees from Kowa Company. Ltd. Ito received research grants and lecture fees from Kowa Company. Ltd. and Takeda Pharmaceutical Company Ltd. Saito has no conflict of interest associated with this research.

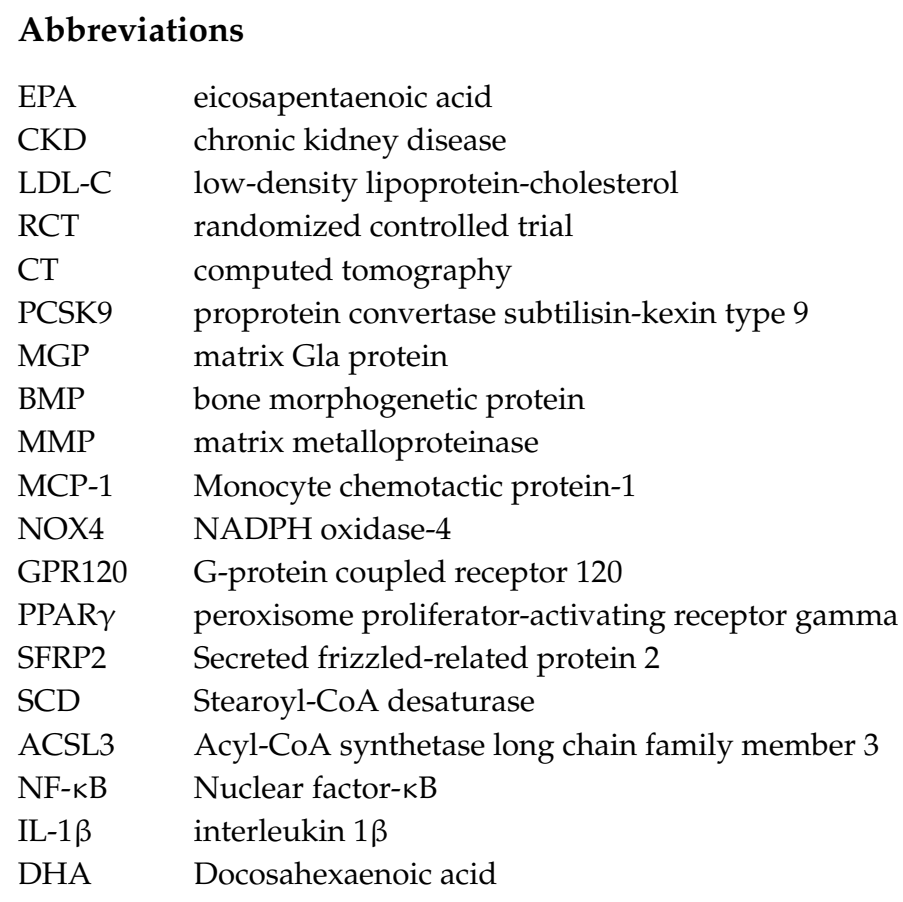




\section{References}

1. Madhavan, M.V.; Tarigopula, M.; Mintz, G.S.; Maehara, A.; Stone, G.W.; Genereux, P. Coronary artery calcification: Pathogenesis and prognostic implications. J. Am. Coll. Cardiol. 2014, 63, 1703-1714. [CrossRef] [PubMed]

2. Budoff, M.J.; Shaw, L.J.; Liu, S.T.; Weinstein, S.R.; Tseng, P.H.; Flores, F.R.; Callister, T.Q.; Raggi, P.; Berman, D.S.; Mosler, T.P. Long-Term Prognosis Associated With Coronary Calcification: Observations From a Registry of 25,253 Patients. J. Am. Coll. Cardiol. 2007, 49, 1860-1870. [CrossRef] [PubMed]

3. Verbeke, F.; van Biesen, W.; Honkanen, E.; Wikström, B.; Jensen, P.B.; Krzesinski, J.-M.; Rasmussen, M.; Vanholder, R.; Rensma, P.L. Prognostic Value of Aortic Stiffness and Calcification for Cardiovascular Events and Mortality in Dialysis Patients: Outcome of the Calcification Outcome in Renal Disease (CORD) Study. Clin. J. Am. Soc. Nephrol. 2011, 6, 153. [CrossRef]

4. Akers, E.J.; Nicholls, S.J.; Bartolo, B.A.D. Plaque Calcification. Arterioscler. Thromb. Vasc. Biol. 2019, 39, 1902-1910. [CrossRef]

5. Shi, X.; Gao, J.; Lv, Q.; Cai, H.; Wang, F.; Ye, R.; Liu, X. Calcification in Atherosclerotic Plaque Vulnerability: Friend or Foe? Front. Physiol. 2020, 11, 56. [CrossRef]

6. Mackey, R.H.; Venkitachalam, L.; Sutton-Tyrrell, K. Calcifications, arterial stiffness and atherosclerosis. Adv. Cardiol. 2007, 44, 234-244.

7. Mattace-Raso, F.U.S.; van der Cammen, T.J.M.; Hofman, A.; van Popele, N.M.; Bos, M.L.; Schalekamp, M.A.D.H.; Asmar, R.; Reneman, R.S.; Hoeks, A.P.G.; Breteler, M.M.B.; et al. Arterial Stiffness and Risk of Coronary Heart Disease and Stroke. Circulation 2006, 113, 657-663. [CrossRef]

8. Henein, M.; Granåsen, G.; Wiklund, U.; Schmermund, A.; Guerci, A.; Erbel, R.; Raggi, P. High dose and long-term statin therapy accelerate coronary artery calcification. Int. J. Cardiol. 2015, 184, 581-586. [CrossRef] [PubMed]

9. Baigent, C.; Keech, A.; Kearney, P.M.; Blackwell, L.; Buck, G.; Pollicino, C.; Kirby, A.; Sourjina, T.; Peto, R.; Collins, R.; et al. Efficacy and safety of cholesterol-lowering treatment: Prospective meta-analysis of data from 90,056 participants in 14 randomised trials of statins. Lancet 2005, 366, 1267-1278.

10. Saremi, A.; Bahn, G.; Reaven, P.D. Progression of vascular calcification is increased with statin use in the Veterans Affairs Diabetes Trial (VADT). Diabetes Care 2012, 35, 2390-2392. [CrossRef]

11. Budoff, M.; Brent Muhlestein, J.; Le, V.T.; May, H.T.; Roy, S.; Nelson, J.R. Effect of Vascepa (icosapent ethyl) on progression of coronary atherosclerosis in patients with elevated triglycerides (200-499 mg/dL) on statin therapy: Rationale and design of the EVAPORATE study. Clin. Cardiol. 2018, 41, 13-19. [CrossRef]

12. Shea, M.K.; O'Donnell, C.J.; Hoffmann, U.; Dallal, G.E.; Dawson-Hughes, B.; Ordovas, J.M.; Price, P.A.; Williamson, M.K.; Booth, S.L. Vitamin K supplementation and progression of coronary artery calcium in older men and women. Am. J. Clin. Nutr. 2009, 89, 1799-1807. [CrossRef] [PubMed]

13. Krueger, T.; Schlieper, G.; Schurgers, L.; Cornelis, T.; Cozzolino, M.; Jacobi, J.; Jadoul, M.; Ketteler, M.; Rump, L.C.; Stenvinkel, P.; et al. Vitamin K1 to slow vascular calcification in haemodialysis patients (VitaVasK trial): A rationale and study protocol. Nephrol. Dial. Transpl. 2014, 29, 1633-1638. [CrossRef] [PubMed]

14. Ikegami, Y.; Inoue, I.; Inoue, K.; Shinoda, Y.; Iida, S.; Goto, S.; Nakano, T.; Shimada, A.; Noda, M. The annual rate of coronary artery calcification with combination therapy with a PCSK9 inhibitor and a statin is lower than that with statin monotherapy. NPJ. Aging. Mech. Dis. 2018, 4, 7. [CrossRef] [PubMed]

15. Ter Braake, A.D.; Smit, A.E.; Bos, C.; van Herwaarden, A.E.; Alkema, W.; van Essen, H.W.; Bravenboer, N.; Vervloet, M.G.; Hoenderop, J.G.J.; de Baaij, J.H.F. Magnesium prevents vascular calcification in Klotho deficiency. Kidney Int. 2020, 97, 487-501. [CrossRef]

16. Voelkl, J.; Alesutan, I.; Leibrock, C.B.; Quintanilla-Martinez, L.; Kuhn, V.; Feger, M.; Mia, S.; Ahmed, M.S.E.; Rosenblatt, K.P.; Kuro-O, M.; et al. Spironolactone ameliorates PIT1-dependent vascular osteoinduction in klotho-hypomorphic mice. J. Clin Investig. 2013, 123, 812-822. [PubMed]

17. Abedin, M.; Lim, J.; Tang, T.B.; Park, D.; Demer, L.L.; Tintut, Y. N-3 fatty acids inhibit vascular calcification via the p38-mitogen-activated protein kinase and peroxisome proliferator-activated receptor-gamma pathways. Circ. Res. 2006, 98, 727-729. [CrossRef] [PubMed]

18. Nakamura, K.; Miura, D.; Saito, Y.; Yunoki, K.; Koyama, Y.; Satoh, M.; Kondo, M.; Osawa, K.; Hatipoglu, O.F.; Miyoshi, T.; et al. Eicosapentaenoic acid prevents arterial calcification in klotho mutant mice. PLoS ONE 2017, 12, e0181009. [CrossRef] 
19. Kanai, S.; Uto, K.; Honda, K.; Hagiwara, N.; Oda, H. Eicosapentaenoic acid reduces warfarin-induced arterial calcification in rats. Atherosclerosis 2011, 215, 43-51. [CrossRef]

20. Wei, M.Y.; Jacobson, T.A. Effects of eicosapentaenoic acid versus docosahexaenoic acid on serum lipids: A systematic review and meta-analysis. Curr. Atheroscler. Rep. 2011, 13, 474-483. [CrossRef]

21. Jacobson, T.A.; Glickstein, S.B.; Rowe, J.D.; Soni, P.N. Effects of eicosapentaenoic acid and docosahexaenoic acid on low-density lipoprotein cholesterol and other lipids: A review. J. Clin. Lipidol. 2012, 6, 5-18. [CrossRef] [PubMed]

22. Bhatt, D.L.; Steg, P.G.; Miller, M.; Brinton, E.A.; Jacobson, T.A.; Ketchum, S.B.; Doyle, R.T., Jr.; Juliano, R.A.; Jiao, L.; Granowitz, C.; et al. Cardiovascular Risk Reduction with Icosapent Ethyl for Hypertriglyceridemia. N. Engl. J. Med. 2019, 380, 11-22. [CrossRef]

23. Yokoyama, M.; Origasa, H.; Matsuzaki, M.; Matsuzawa, Y.; Saito, Y.; Ishikawa, Y.; Oikawa, S.; Sasaki, J.; Hishida, H.; Itakura, H.; et al. Effects of eicosapentaenoic acid on major coronary events in hypercholesterolaemic patients (JELIS): A randomised open-label, blinded endpoint analysis. Lancet 2007, 369, 1090-1098. [CrossRef]

24. Bhatt, D.L.; Miller, M.; Brinton, E.A.; Jacobson, T.A.; Steg, P.G.; Ketchum, S.B.; Doyle, R.T., Jr.; Juliano, R.A.; Jiao, L.; Granowitz, C.; et al. REDUCE-IT USA: Results From the 3146 Patients Randomized in the United States. Circulation 2020, 141, 367-375. [CrossRef] [PubMed]

25. Bittner, D.O.; Goeller, M.; Zopf, Y.; Achenbach, S.; Marwan, M. Early-onset coronary atherosclerosis in patients with low levels of omega-3 fatty acids. Eur. J. Clin. Nutr. 2020, 74, 651-656. [CrossRef] [PubMed]

26. Miyoshi, T.; Kohno, K.; Asonuma, H.; Sakuragi, S.; Nakahama, M.; Kawai, Y.; Uesugi, T.; Oka, T.; Munemasa, M.; Takahashi, N.; et al. Effect of Intensive and Standard Pitavastatin Treatment With or Without Eicosapentaenoic Acid on Progression of Coronary Artery Calcification Over 12 Months- Prospective Multicenter Study. Circ. J. 2018, 82, 532-540. [CrossRef]

27. Sekikawa, A.; Mahajan, H.; Kadowaki, S.; Hisamatsu, T.; Miyagawa, N.; Fujiyoshi, A.; Kadota, A.; Maegawa, H.; Murata, K.; Miura, K.; et al. Association of blood levels of marine omega-3 fatty acids with coronary calcification and calcium density in Japanese men. Eur. J. Clin. Nutr. 2019, 73, 783-792. [CrossRef]

28. Sekikawa, A.; Miura, K.; Lee, S.; Fujiyoshi, A.; Edmundowicz, D.; Kadowaki, T.; Evans, R.W.; Kadowaki, S.; Sutton-Tyrrell, K.; Okamura, T.; et al. Long chain n-3 polyunsaturated fatty acids and incidence rate of coronary artery calcification in Japanese men in Japan and white men in the USA: Population based prospective cohort study. Heart 2014, 100, 569-573. [CrossRef]

29. Serhan, C.N.; Hong, S.; Gronert, K.; Colgan, S.P.; Devchand, P.R.; Mirick, G.; Moussignac, R.L. Resolvins: A family of bioactive products of omega-3 fatty acid transformation circuits initiated by aspirin treatment that counter proinflammation signals. J. Exp. Med. 2002, 196, 1025-1037. [CrossRef]

30. Schwab, J.M.; Chiang, N.; Arita, M.; Serhan, C.N. Resolvin E1 and protectin D1 activate inflammationresolution programmes. Nature 2007, 447, 869-874. [CrossRef]

31. Boekholdt, S.M.; Hovingh, G.K.; Mora, S.; Arsenault, B.J.; Amarenco, P.; Pedersen, T.R.; LaRosa, J.C.; Waters, D.D.; DeMicco, D.A.; Simes, R.J.; et al. Very low levels of atherogenic lipoproteins and the risk for cardiovascular events: A meta-analysis of statin trials. J. Am. Coll. Cardiol. 2014, 64, 485-494. [CrossRef] [PubMed]

32. Ginsberg, H.N.; Elam, M.B.; Lovato, L.C.; Crouse 3rd, J.R.; Leiter, L.A.; Linz, P.; Friedewald, W.T.; Buse, J.B.; Gerstein, H.C.; Probstfield, J.; et al. Effects of combination lipid therapy in type 2 diabetes mellitus. N. Engl. J. Med. 2010, 362, 1563-1574. [PubMed]

33. Group, H.T.C.; Landray, M.J.; Haynes, R.; Hopewell, J.C.; Parish, S.; Aung, T.; Tomson, J.; Wallendszus, K.; Craig, M.; Jiang, L.; et al. Effects of extended-release niacin with laropiprant in high-risk patients. N. Engl. J. Med. 2014, 371, 203-212.

34. Investigators, A.-H. The role of niacin in raising high-density lipoprotein cholesterol to reduce cardiovascular events in patients with atherosclerotic cardiovascular disease and optimally treated low-density lipoprotein cholesterol Rationale and study design. The Atherothrombosis Intervention in Metabolic syndrome with low HDL/high triglycerides: Impact on Global Health outcomes (AIM-HIGH). Am. Heart J. 2011, 161, 471-477.

35. Investigators, O.T.; Bosch, J.; Gerstein, H.C.; Dagenais, G.R.; Diaz, R.; Dyal, L.; Jung, H.; Maggiono, A.P.; Probstfield, J.; Ramachandran, A.; et al. n-3 fatty acids and cardiovascular outcomes in patients with dysglycemia. N. Engl. J. Med. 2012, 367, 309-318. [CrossRef] 
36. Group, A.S.C.; Bowman, L.; Mafham, M.; Wallendszus, K.; Stevens, W.; Buck, G.; Barton, J.; Murphy, K.; Aung, T.; Haynes, R.; et al. Effects of n-3 Fatty Acid Supplements in Diabetes Mellitus. N. Engl. J. Med. 2018, $379,1540-1550$.

37. Aung, T.; Halsey, J.; Kromhout, D.; Gerstein, H.C.; Marchioli, R.; Tavazzi, L.; Geleijnse, J.M.; Rauch, B.; Ness, A.; Galan, P.; et al. Associations of Omega-3 Fatty Acid Supplement Use With Cardiovascular Disease Risks: Meta-analysis of 10 Trials Involving 77917 Individuals. JAMA. Cardiol. 2018, 3, 225-234. [CrossRef]

38. Borow, K.M.; Nelson, J.R.; Mason, R.P. Biologic plausibility, cellular effects, and molecular mechanisms of eicosapentaenoic acid (EPA) in atherosclerosis. Atherosclerosis 2015, 242, 357-366. [CrossRef]

39. Tani, S.; Nagao, K.; Matsumoto, M.; Hirayama, A. Highly Purified Eicosapentaenoic Acid May Increase Low-Density Lipoprotein Particle Size by Improving Triglyceride Metabolism in Patients with Hypertriglyceridemia. Circ. J. 2013, 77, 2349-2357. [CrossRef]

40. Satoh, N.; Shimatsu, A.; Kotani, K.; Sakane, N.; Yamada, K.; Suganami, T.; Kuzuya, H.; Ogawa, Y. Purified Eicosapentaenoic Acid Reduces Small Dense LDL, Remnant Lipoprotein Particles, and C-Reactive Protein in Metabolic Syndrome. Diabetes Care 2007, 30, 144. [CrossRef]

41. Nakajima, K.; Yamashita, T.; Kita, T.; Takeda, M.; Sasaki, N.; Kasahara, K.; Shinohara, M.; Rikitake, Y.; Ishida, T.; Yokoyama, M.; et al. Orally Administered Eicosapentaenoic Acid Induces Rapid Regression of Atherosclerosis Via Modulating the Phenotype of Dendritic Cells in LDL Receptor-Deficient Mice. Arter. Thromb. Vasc. Biol. 2011, 31, 1963-1972. [CrossRef]

42. Matsumoto, M.; Sata, M.; Fukuda, D.; Tanaka, K.; Soma, M.; Hirata, Y.; Nagai, R. Orally administered eicosapentaenoic acid reduces and stabilizes atherosclerotic lesions in ApoE-deficient mice. Atherosclerosis 2008, 197, 524-533. [CrossRef]

43. Kamata, R.; Bumdelger, B.; Kokubo, H.; Fujii, M.; Yoshimura, K.; Ishida, T.; Ishida, M.; Yoshizumi, M. EPA Prevents the Development of Abdominal Aortic Aneurysms through Gpr-120/Ffar-4. PLoS ONE 2016, 11, e0165132. [CrossRef]

44. Sato, T.; Horikawa, M.; Takei, S.; Yamazaki, F.; Ito, T.K.; Kondo, T.; Sakurai, T.; Kahyo, T.; Ikegami, K.; Sato, S.; et al. Preferential Incorporation of Administered Eicosapentaenoic Acid Into Thin-Cap Atherosclerotic Plaques. Arterioscler. Thromb. Vasc. Biol. 2019, 39, 1802-1816. [CrossRef]

45. Kronmal, R.A.; McClelland, R.L.; Detrano, R.; Shea, S.; Lima, J.A.; Cushman, M.; Bild, D.E.; Burke, G.L. Risk factors for the progression of coronary artery calcification in asymptomatic subjects: Results from the Multi-Ethnic Study of Atherosclerosis (MESA). Circulation 2007, 115, 2722-2730. [CrossRef]

46. Budoff, M.J.; Hokanson, J.E.; Nasir, K.; Shaw, L.J.; Kinney, G.L.; Chow, D.; Demoss, D.; Nuguri, V.; Nabavi, V.; Ratakonda, R.; et al. Progression of coronary artery calcium predicts all-cause mortality. JACC Cardiovasc. Imaging 2010, 3, 1229-1236. [CrossRef]

47. Amann, K. Media Calcification and Intima Calcification Are Distinct Entities in Chronic Kidney Disease. Clin. J. Am. Soc. Nephrol. 2008, 3, 1599. [CrossRef]

48. Zazzeroni, L.; Faggioli, G.; Pasquinelli, G. Mechanisms of Arterial Calcification: The Role of Matrix Vesicles. Eur. J. Vasc. Endovasc. Surg. 2018, 55, 425-432. [CrossRef]

49. Wang, Y.; Osborne, M.T.; Tung, B.; Li, M.; Li, Y. Imaging Cardiovascular Calcification. J. Am. Heart Assoc. 2018, 7, e008564.

50. Blacher, J.; Guerin Alain, P.; Pannier, B.; Marchais Sylvain, J.; London Gérard, M. Arterial Calcifications, Arterial Stiffness, and Cardiovascular Risk in End-Stage Renal Disease. Hypertension 2001, 38, 938-942. [CrossRef]

51. Rennenberg, R.J.; Kessels, A.G.; Schurgers, L.J.; van Engelshoven, J.M.; de Leeuw, P.W.; Kroon, A.A. Vascular calcifications as a marker of increased cardiovascular risk: A meta-analysis. Vasc. Health. Risk. Manag. 2009, 5, 185-197. [CrossRef]

52. Vengrenyuk, Y.; Carlier, S.; Xanthos, S.; Cardoso, L.; Ganatos, P.; Virmani, R.; Einav, S.; Gilchrist, L.; Weinbaum, S. A hypothesis for vulnerable plaque rupture due to stress-induced debonding around cellular microcalcifications in thin fibrous caps. Proc. Natl. Acad. Sci. USA 2006, 103, 14678-14683. [CrossRef]

53. Kelly-Arnold, A.; Maldonado, N.; Laudier, D.; Aikawa, E.; Cardoso, L.; Weinbaum, S. Revised microcalcification hypothesis for fibrous cap rupture in human coronary arteries. Proc. Natl. Acad. Sci. USA 2013, 110, 10741-10746. [CrossRef]

54. Huang, H.; Virmani, R.; Younis, H.; Burke, A.P.; Kamm, R.D.; Lee, R.T. The Impact of Calcification on the Biomechanical Stability of Atherosclerotic Plaques. Circulation 2001, 103, 1051-1056. [CrossRef] 
55. Vengrenyuk, Y.; Cardoso, L.; Weinbaum, S. Micro-CT based analysis of a new paradigm for vulnerable plaque rupture: Cellular microcalcifications in fibrous caps. Mol. Cell Biomech. 2008, 5, 37-47.

56. Guérin, A.P.; London, G.M.; Marchais, S.J.; Metivier, F. Arterial stiffening and vascular calcifications in end-stage renal disease. Nephrol. Dial. Transplant. 2000, 15, 1014-1021. [CrossRef]

57. Osawa, K.; Miyoshi, T.; Oe, H.; Sato, S.; Nakamura, K.; Kohno, K.; Morita, H.; Kanazawa, S.; Ito, H. Association between coronary artery calcification and left ventricular diastolic dysfunction in elderly people. Heart Vessel. 2016, 31, 499-507. [CrossRef]

58. Nakazato, R.; Gransar, H.; Berman, D.S.; Cheng, V.Y.; Lin, F.Y.; Achenbach, S.; Al-Mallah, M.; Budoff, M.J.; Cademartiri, F.; Callister, T.Q.; et al. Statins use and coronary artery plaque composition: Results from the International Multicenter CONFIRM Registry. Atherosclerosis 2012, 225, 148-153. [CrossRef]

59. Puri, R.; Nicholls, S.J.; Shao, M.; Kataoka, Y.; Uno, K.; Kapadia, S.R.; Tuzcu, E.M.; Nissen, S.E. Impact of Statins on Serial Coronary Calcification During Atheroma Progression and Regression. J. Am. Coll. Cardiol. 2015, 65, 1273-1282. [CrossRef]

60. Healy, A.; Berus, J.M.; Christensen, J.L.; Lee, C.; Mantsounga, C.; Dong, W.; Watts, J.P.; Assali, M.; Ceneri, N.; Nilson, R.; et al. Statins Disrupt Macrophage Rac1 Regulation Leading to Increased Atherosclerotic Plaque Calcification. Arterioscler. Thromb. Vasc. Biol. 2020, 40, 714-732. [CrossRef]

61. Ceneri, N.; Zhao, L.; Young, B.D.; Healy, A.; Coskun, S.; Vasavada, H.; Yarovinsky, T.O.; Ike, K.; Pardi, R.; Qin, L.; et al. Rac2 Modulates Atherosclerotic Calcification by Regulating Macrophage Interleukin-1 $\beta$ Production. Arterioscler. Thromb. Vasc. Biol. 2017, 37, 328-340. [CrossRef]

62. Fu, H.; Alabdullah, M.; Großmann, J.; Spieler, F.; Abdosh, R.; Lutz, V.; Kalies, K.; Knöpp, K.; Rieckmann, M.; Koch, S.; et al. The differential statin effect on cytokine production of monocytes or macrophages is mediated by differential geranylgeranylation-dependent Rac1 activation. Cell Death Dis. 2019, 10, 880. [CrossRef]

63. Zhao, X.; Zhang, H.W.; Li, S.; Zhang, Y.; Xu, R.X.; Zhu, C.G.; Wu, N.Q.; Guo, Y.L.; Qing, P.; Li, X.L.; et al. Association between plasma proprotein convertase subtisilin/kexin type 9 concentration and coronary artery calcification. Ann. Clin. Biochem. 2018, 55, 158-164. [CrossRef]

64. Nozue, T. Lipid Lowering Therapy and Circulating PCSK9 Concentration. J. Atheroscler Thromb. 2017, 24, 895-907. [CrossRef]

65. Nicholls, S.J.; Puri, R.; Anderson, T.; Ballantyne, C.M.; Cho, L.; Kastelein, J.J.P.; Koenig, W.; Somaratne, R.; Kassahun, H.; Yang, J.; et al. Effect of Evolocumab on Coronary Plaque Composition. J. Am. Coll Cardiol. 2018, 72, 2012-2021. [CrossRef]

66. Shao, J.S.; Cai, J.; Towler, D.A. Molecular mechanisms of vascular calcification: Lessons learned from the aorta. Arter. Thromb. Vasc. Biol. 2006, 26, 1423-1430. [CrossRef]

67. Nakahara, T.; Dweck, M.R.; Narula, N.; Pisapia, D.; Narula, J.; Strauss, H.W. Coronary Artery Calcification: From Mechanism to Molecular Imaging. Jacc. Cardiovasc. Imaging 2017, 10, 582-593. [CrossRef]

68. Abdelbaky, A.; Corsini, E.; Figueroa Amparo, L.; Fontanez, S.; Subramanian, S.; Ferencik, M.; Brady Thomas, J.; Hoffmann, U.; Tawakol, A. Focal Arterial Inflammation Precedes Subsequent Calcification in the Same Location. Circ. Cardiovasc. Imaging 2013, 6, 747-754. [CrossRef]

69. Cozzolino, M.; Brancaccio, D.; Gallieni, M.; Slatopolsky, E. Pathogenesis of vascular calcification in chronic kidney disease. Kidney Int. 2005, 68, 429-436. [CrossRef]

70. Van Campenhout, A.; Golledge, J. Osteoprotegerin, vascular calcification and atherosclerosis. Atherosclerosis 2009, 204, 321-329. [CrossRef]

71. Giachelli, C.M.; Speer, M.Y.; Li, X.; Rajachar, R.M.; Yang, H. Regulation of vascular calcification: Roles of phosphate and osteopontin. Circ. Res. 2005, 96, 717-722. [CrossRef]

72. Vassalle, C.; Iervasi, G. New insights for matrix Gla protein, vascular calcification and cardiovascular risk and outcome. Atherosclerosis 2014, 235, 236-238. [CrossRef] [PubMed]

73. Lomashvili, K.A.; Narisawa, S.; Millán, J.L.; O'Neill, W.C. Vascular calcification is dependent on plasma levels of pyrophosphate. Kidney Int. 2014, 85, 1351-1356. [CrossRef] [PubMed]

74. Schurgers, L.J.; Akbulut, A.C.; Kaczor, D.M.; Halder, M.; Koenen, R.R.; Kramann, R. Initiation and Propagation of Vascular Calcification is Regulated by a Concert of Platelet- and Smooth Muscle Cell-Derived Extracellular Vesicles. Front. Cardiovasc. Med. 2018, 5, 36. [CrossRef]

75. Proudfoot, D.; Skepper, J.N.; Hegyi, L.; Bennett, M.R.; Shanahan, C.M.; Weissberg, P.L. Apoptosis regulates human vascular calcification in vitro: Evidence for initiation of vascular calcification by apoptotic bodies. Circ. Res. 2000, 87, 1055-1062. [CrossRef] 
76. Thompson, B.; Towler, D.A. Arterial calcification and bone physiology: Role of the bone-vascular axis. Nat. Rev. Endocrinol. 2012, 8, 529-543. [CrossRef]

77. Lee, S.J.; Lee, I.K.; Jeon, J.H. Vascular Calcification-New Insights Into Its Mechanism. Int. J. Mol. Sci. 2020, 21, 2685. [CrossRef]

78. Saito, Y.; Nakamura, K.; Miura, D.; Yunoki, K.; Miyoshi, T.; Yoshida, M.; Kawakita, N.; Kimura, T.; Kondo, M.; Sarashina, T.; et al. Suppression of Wnt Signaling and Osteogenic Changes in Vascular Smooth Muscle Cells by Eicosapentaenoic Acid. Nutrients 2017, 9, 858. [CrossRef]

79. Kageyama, A.; Matsui, H.; Ohta, M.; Sambuichi, K.; Kawano, H.; Notsu, T.; Imada, K.; Yokoyama, T.; Kurabayashi, M. Palmitic Acid Induces Osteoblastic Differentiation in Vascular Smooth Muscle Cells through ACSL3 and NF-кB, Novel Targets of Eicosapentaenoic Acid. PLoS ONE 2013, 8, e68197. [CrossRef]

80. Luo, G.; Ducy, P.; McKee, M.D.; Pinero, G.J.; Loyer, E.; Behringer, R.R.; Karsenty, G. Spontaneous calcification of arteries and cartilage in mice lacking matrix GLA protein. Nature 1997, 386, 78-81. [CrossRef]

81. Speer, M.Y.; McKee, M.D.; Guldberg, R.E.; Liaw, L.; Yang, H.Y.; Tung, E.; Karsenty, G.; Giachelli, C.M. Inactivation of the osteopontin gene enhances vascular calcification of matrix Gla protein-deficient mice: Evidence for osteopontin as an inducible inhibitor of vascular calcification in vivo. J. Exp. Med. 2002, 196, 1047-1055. [CrossRef] [PubMed]

82. Jaminon, A.M.G.; Dai, L.; Qureshi, A.R.; Evenepoel, P.; Ripsweden, J.; Söderberg, M.; Witasp, A.; Olauson, H.; Schurgers, L.J.; Stenvinkel, P. Matrix Gla protein is an independent predictor of both intimal and medial vascular calcification in chronic kidney disease. Sci. Rep. 2020, 10, 6586. [CrossRef] [PubMed]

83. Zebboudj, A.F.; Imura, M.; Boström, K. Matrix GLA Protein, a Regulatory Protein for Bone Morphogenetic Protein-2. J. Biol. Chem. 2002, 277, 4388-4394. [CrossRef] [PubMed]

84. Zebboudj, A.F.; Shin, V.; Boström, K. Matrix GLA protein and BMP-2 regulate osteoinduction in calcifying vascular cells. J. Cell. Biochem. 2003, 90, 756-765. [CrossRef]

85. Schurgers, L.J.; Teunissen, K.J.; Knapen, M.H.; Kwaijtaal, M.; van Diest, R.; Appels, A.; Reutelingsperger, C.P.; Cleutjens, J.P.; Vermeer, C. Novel conformation-specific antibodies against matrix gamma-carboxyglutamic acid (Gla) protein: Undercarboxylated matrix Gla protein as marker for vascular calcification. Arter. Thromb. Vasc. Biol. 2005, 25, 1629-1633. [CrossRef]

86. Demer, L.L.; Boström, K.I. Conflicting forces of warfarin and matrix gla protein in the artery wall. Arter. Thromb. Vasc. Biol. 2015, 35, 9-10. [CrossRef]

87. Price, P.A.; Faus, S.A.; Williamson, M.K. Warfarin causes rapid calcification of the elastic lamellae in rat arteries and heart valves. Arter. Thromb. Vasc. Biol. 1998, 18, 1400-1407. [CrossRef]

88. Price, P.A.; Kaneda, Y. Vitamin K counteracts the effect of warfarin in liver but not in bone. Thromb. Res. 1987, 46, 121-131. [CrossRef]

89. Kuro-o, M.; Matsumura, Y.; Aizawa, H.; Kawaguchi, H.; Suga, T.; Utsugi, T.; Ohyama, Y.; Kurabayashi, M.; Kaname, T.; Kume, E.; et al. Mutation of the mouse klotho gene leads to a syndrome resembling ageing. Nature 1997, 390, 45-51. [CrossRef]

90. Kurosu, H.; Yamamoto, M.; Clark, J.D.; Pastor, J.V.; Nandi, A.; Gurnani, P.; McGuinness, O.P.; Chikuda, H.; Yamaguchi, M.; Kawaguchi, H.; et al. Suppression of aging in mice by the hormone Klotho. Science 2005, 309, 1829-1833. [CrossRef]

91. Semba, R.D.; Cappola, A.R.; Sun, K.; Bandinelli, S.; Dalal, M.; Crasto, C.; Guralnik, J.M.; Ferrucci, L. Plasma klotho and mortality risk in older community-dwelling adults. J. Gerontol. A Biol. Sci. Med. Sci 2011, 66, 794-800. [CrossRef] [PubMed]

92. Semba, R.D.; Cappola, A.R.; Sun, K.; Bandinelli, S.; Dalal, M.; Crasto, C.; Guralnik, J.M.; Ferrucci, L. Plasma klotho and cardiovascular disease in adults. J. Am. Geriatr. Soc. 2011, 59, 1596-1601. [CrossRef]

93. Kitagawa, M.; Sugiyama, H.; Morinaga, H.; Inoue, T.; Takiue, K.; Ogawa, A.; Yamanari, T.; Kikumoto, Y.; Uchida, H.A.; Kitamura, S.; et al. A decreased level of serum soluble Klotho is an independent biomarker associated with arterial stiffness in patients with chronic kidney disease. PLoS ONE 2013, 8, e56695. [CrossRef] [PubMed]

94. Koh, N.; Fujimori, T.; Nishiguchi, S.; Tamori, A.; Shiomi, S.; Nakatani, T.; Sugimura, K.; Kishimoto, T.; Kinoshita, S.; Kuroki, T.; et al. Severely Reduced Production of Klotho in Human Chronic Renal Failure Kidney. Biochem. Biophys. Res. Commun. 2001, 280, 1015-1020. [CrossRef] [PubMed]

95. Griendling, K.K.; Sorescu, D.; Ushio-Fukai, M. NAD(P)H Oxidase. Circ. Res. 2000, 86, 494-501. [CrossRef] [PubMed] 
96. Byon, C.H.; Javed, A.; Dai, Q.; Kappes, J.C.; Clemens, T.L.; Darley-Usmar, V.M.; McDonald, J.M.; Chen, Y. Oxidative stress induces vascular calcification through modulation of the osteogenic transcription factor Runx2 by AKT signaling. J. Biol. Chem. 2008, 283, 15319-15327. [CrossRef]

97. Hu, M.C.; Shi, M.; Zhang, J.; Quiñones, H.; Griffith, C.; Kuro-o, M.; Moe, O.W. Klotho deficiency causes vascular calcification in chronic kidney disease. J. Am. Soc. Nephrol. 2011, 22, 124-136. [CrossRef]

98. Nusse, R.; Clevers, H. Wnt/ $\beta$-Catenin Signaling, Disease, and Emerging Therapeutic Modalities. Cell 2017, 169, 985-999. [CrossRef]

99. Steinhart, Z.; Angers, S. Wnt signaling in development and tissue homeostasis. Development 2018, 145, dev146589. [CrossRef]

100. Lehmann, M.; Baarsma, H.A.; Königshoff, M. WNT Signaling in Lung Aging and Disease. Ann. Am. Thorac. Soc. 2016, 13, s411-s416. [CrossRef]

101. Yang, H.C.; Fogo, A.B. Fibrosis and renal aging. Kidney Int. Suppl. 2014, 4, 75-78. [CrossRef]

102. Freise, C.; Kretzschmar, N.; Querfeld, U. Wnt signaling contributes to vascular calcification by induction of matrix metalloproteinases. BMC Cardiovasc. Disord. 2016, 16, 185. [CrossRef]

103. Albanese, I.; Khan, K.; Barratt, B.; Al-Kindi, H.; Schwertani, A. Atherosclerotic Calcification: Wnt Is the Hint. J. Am. Heart Assoc. 2018, 7, 4. [CrossRef]

104. Shao, J.S.; Cheng, S.L.; Pingsterhaus, J.M.; Charlton-Kachigian, N.; Loewy, A.P.; Towler, D.A. Msx2 promotes cardiovascular calcification by activating paracrine Wnt signals. J. Clin. Investig. 2005, 115, 1210-1220. [CrossRef]

105. Liu, H.; Fergusson, M.M.; Castilho, R.M.; Liu, J.; Cao, L.; Chen, J.; Malide, D.; Rovira, I.I.; Schimel, D.; Kuo, C.J.; et al. Augmented Wnt signaling in a mammalian model of accelerated aging. Science 2007, 317, 803-806. [CrossRef]

106. Song, K.S.; Jing, K.; Kim, J.S.; Yun, E.J.; Shin, S.; Seo, K.S.; Park, J.H.; Heo, J.Y.; Kang, J.X.; Suh, K.S.; et al. Omega-3-polyunsaturated fatty acids suppress pancreatic cancer cell growth in vitro and in vivo via downregulation of Wnt/Beta-catenin signaling. Pancreatology 2011, 11, 574-584. [CrossRef]

107. Devi, K.P.; Rajavel, T.; Russo, G.L.; Daglia, M.; Nabavi, S.F.; Nabavi, S.M. Molecular Targets of Omega-3 Fatty Acids for Cancer Therapy. Anticancer Agents Med. Chem. 2015, 15, 888-895. [CrossRef]

108. Cai, T.; Sun, D.; Duan, Y.; Wen, P.; Dai, C.; Yang, J.; He, W. WNT/ $\beta$-catenin signaling promotes VSMCs to osteogenic transdifferentiation and calcification through directly modulating Runx2 gene expression. Exp. Cell Res. 2016, 345, 206-217. [CrossRef]

109. Woldt, E.; Terrand, J.; Mlih, M.; Matz, R.L.; Bruban, V.; Coudane, F.; Foppolo, S.; El Asmar, Z.; Chollet, M.E.; Ninio, E.; et al. The nuclear hormone receptor PPAR $\gamma$ counteracts vascular calcification by inhibiting Wnt5a signalling in vascular smooth muscle cells. Nat. Commun. 2012, 3, 1077. [CrossRef]

110. Boucher, P.; Matz, R.L.; Terrand, J. atherosclerosis: Gone with the Wnt? Atherosclerosis 2020, 301, 15-22. [CrossRef]

111. Cohen, P.; Miyazaki, M.; Socci, N.D.; Hagge-Greenberg, A.; Liedtke, W.; Soukas, A.A.; Sharma, R.; Hudgins, L.C.; Ntambi, J.M.; Friedman, J.M. Role for stearoyl-CoA desaturase-1 in leptin-mediated weight loss. Science 2002, 297, 240-243. [CrossRef] [PubMed]

112. Paton, C.M.; Ntambi, J.M. Biochemical and physiological function of stearoyl-CoA desaturase. Am. J. Physiol. Endocrinol. Metab. 2009, 297, E28-E37. [CrossRef]

113. Miyazaki, M.; Ntambi, J.M. Role of stearoyl-coenzyme A desaturase in lipid metabolism. Prostaglandins Leukot Essent Fat. Acids 2003, 68, 113-121. [CrossRef]

114. Masuda, M.; Miyazaki-Anzai, S.; Keenan, A.L.; Okamura, K.; Kendrick, J.; Chonchol, M.; Offermanns, S.; Ntambi, J.M.; Kuro, O.M.; Miyazaki, M. Saturated phosphatidic acids mediate saturated fatty acid-induced vascular calcification and lipotoxicity. J. Clin. Investig. 2015, 125, 4544-4558. [CrossRef] [PubMed]

115. Zong, G.; Li, Y.; Wanders, A.J.; Alssema, M.; Zock, P.L.; Willett, W.C.; Hu, F.B.; Sun, Q. Intake of individual saturated fatty acids and risk of coronary heart disease in US men and women: Two prospective longitudinal cohort studies. BMJ 2016, 355, i5796. [CrossRef]

116. Praagman, J.; Vissers, L.E.T.; Mulligan, A.A.; Laursen, A.S.D.; Beulens, J.W.J.; van der Schouw, Y.T.; Wareham, N.J.; Hansen, C.P.; Khaw, K.-T.; Jakobsen, M.U.; et al. Consumption of individual saturated fatty acids and the risk of myocardial infarction in a UK and a Danish cohort. Int. J. Cardiol. 2019, 279, 18-26. [CrossRef] 
117. Brodeur, M.R.; Bouvet, C.; Barrette, M.; Moreau, P. Palmitic acid increases medial calcification by inducing oxidative stress. J. Vasc. Res. 2013, 50, 430-441. [CrossRef]

118. Henriksbo, B.D.; Tamrakar, A.K.; Xu, J.; Duggan, B.M.; Cavallari, J.F.; Phulka, J.; Stampfli, M.R.; Ashkar, A.A.; Schertzer, J.D. Statins Promote Interleukin-1 $\beta$-Dependent Adipocyte Insulin Resistance Through Lower Prenylation, Not Cholesterol. Diabetes 2019, 68, 1441-1448. [CrossRef]

119. Awan, Z.; Denis, M.; Roubtsova, A.; Essalmani, R.; Marcinkiewicz, J.; Awan, A.; Gram, H.; Seidah, N.G.; Genest, J. Reducing Vascular Calcification by Anti-IL-1 $\beta$ Monoclonal Antibody in a Mouse Model of Familial Hypercholesterolemia. Angiology 2016, 67, 157-167. [CrossRef]

120. Ridker, P.M.; Everett, B.M.; Thuren, T.; MacFadyen, J.G.; Chang, W.H.; Ballantyne, C.; Fonseca, F.; Nicolau, J.; Koenig, W.; Anker, S.D.; et al. Antiinflammatory Therapy with Canakinumab for Atherosclerotic Disease. N. Engl. J. Med. 2017, 377, 1119-1131. [CrossRef] [PubMed]

121. Morin, C.; Blier, P.U.; Fortin, S. Eicosapentaenoic acid and docosapentaenoic acid monoglycerides are more potent than docosahexaenoic acid monoglyceride to resolve inflammation in a rheumatoid arthritis model. Arthritis Res. Ther. 2015, 17, 142. [CrossRef] [PubMed]

122. Takase, O.; Hishikawa, K.; Kamiura, N.; Nakakuki, M.; Kawano, H.; Mizuguchi, K.; Fujita, T. Eicosapentaenoic acid regulates IKB $\alpha$ and prevents tubulointerstitial injury in kidney. Eur. J. Pharmacol. 2011, 669, 128-135. [CrossRef] [PubMed]

123. Nishio, R.; Shinke, T.; Otake, H.; Nakagawa, M.; Nagoshi, R.; Inoue, T.; Kozuki, A.; Hariki, H.; Osue, T.; Taniguchi, Y.; et al. Stabilizing effect of combined eicosapentaenoic acid and statin therapy on coronary thin-cap fibroatheroma. Atherosclerosis 2014, 234, 114-119. [CrossRef] [PubMed]

124. Niki, T.; Wakatsuki, T.; Yamaguchi, K.; Taketani, Y.; Oeduka, H.; Kusunose, K.; Ise, T.; Iwase, T.; Yamada, H.; Soeki, T.; et al. Effects of the Addition of Eicosapentaenoic Acid to Strong Statin Therapy on Inflammatory Cytokines and Coronary Plaque Components Assessed by Integrated Backscatter Intravascular Ultrasound. Circ. J. 2016, 80, 450-460. [CrossRef]

125. Watanabe, T.; Ando, K.; Daidoji, H.; Otaki, Y.; Sugawara, S.; Matsui, M.; Ikeno, E.; Hirono, O.; Miyawaki, H.; Yashiro, Y.; et al. A randomized controlled trial of eicosapentaenoic acid in patients with coronary heart disease on statins. J. Cardiol. 2017, 70, 537-544. [CrossRef]

126. Budoff, M. Effect of Icosapent Ethyl on prgression of coronary atherosclerosis in patients with elevated tryglycerides on statin therapy: The EVAPORATE study. In Proceedings of the 2019 AHA Scientific Sessions, Philadelphia, PA, USA, 18 November 2019.

127. Fredriksson, R.; Höglund, P.J.; Gloriam, D.E.; Lagerström, M.C.; Schiöth, H.B. Seven evolutionarily conserved human rhodopsin G protein-coupled receptors lacking close relatives. FEBS Lett. 2003, 554, 381-388. [CrossRef]

128. Oh, D.Y.; Talukdar, S.; Bae, E.J.; Imamura, T.; Morinaga, H.; Fan, W.; Li, P.; Lu, W.J.; Watkins, S.M.; Olefsky, J.M. GPR120 is an omega-3 fatty acid receptor mediating potent anti-inflammatory and insulin-sensitizing effects. Cell 2010, 142, 687-698. [CrossRef]

129. Carracedo, M.; Artiach, G.; Witasp, A.; Clària, J.; Carlström, M.; Laguna-Fernandez, A.; Stenvinkel, P.; Bäck, M. The G-protein coupled receptor ChemR23 determines smooth muscle cell phenotypic switching to enhance high phosphate-induced vascular calcification. Cardiovasc. Res. 2018, 115, 1557-1566. [CrossRef]

130. Arita, M.; Bianchini, F.; Aliberti, J.; Sher, A.; Chiang, N.; Hong, S.; Yang, R.; Petasis, N.A.; Serhan, C.N. Stereochemical assignment, antiinflammatory properties, and receptor for the omega-3 lipid mediator resolvin E1. J. Exp. Med. 2005, 201, 713-722. [CrossRef]

131. Carracedo, M.; Witasp, A.; Qureshi, A.R.; Laguna-Fernandez, A.; Brismar, T.; Stenvinkel, P.; Bäck, M. Chemerin inhibits vascular calcification through ChemR23 and is associated with lower coronary calcium in chronic kidney disease. J. Intern. Med. 2019, 286, 449-457. [CrossRef]

(C) 2020 by the authors. Licensee MDPI, Basel, Switzerland. This article is an open access article distributed under the terms and conditions of the Creative Commons Attribution (CC BY) license (http://creativecommons.org/licenses/by/4.0/). 